\title{
METALLOTHIONEIN-LIKE METAL-BINDING PROTEIN IN THE BIOMONITOR CHAOBORUS: OCCURRENCE AND RELATIONSHIP TO AMBIENT METAL CONCENTRATIONS IN LAKES
}

\author{
Marie-Nö̈le Croteau, $\dagger$ Landis Hare, $* \dagger$ Peter G.C. Campbell, $\dagger$ and Yves Couillard $\$$ \\ $\dagger$ Institut National de la Recherche Scientifique-Eau, Université du Québec, C.P. 7500, Sainte-Foy, Québec G1V 4C7, Canada \\ $\ddagger$ Chemicals Evaluation Division, Existing Substances Branch, Environment Canada, Place Vincent Massey, 351 Saint Joseph Boulevard,
} 14th Floor, Hull, Quebec K1A 0H3, Canada

(Received 14 June 2001; Accepted 21 October 2001)

\begin{abstract}
Larvae of the insect Chaoborus are used to monitor cadmium (Cd) in lakes. We set out to determine if this animal possesses a metallothionein-like protein to which its $\mathrm{Cd}$ could be bound and if the concentrations of such a protein are correlated with those of $\mathrm{Cd}$ in the insect and in lakewater. To achieve our goals, we collected water and larvae of several Chaoborus species from 10 lakes situated along an environmental Cd gradient. We found that all of the Chaoborus species possess a metallothioneinlike protein and that concentrations of the protein and of $\mathrm{Cd}$ differed among species. Concentrations of the metallothionein-like protein were directly related to those in Chaoborus and in lakewater. These direct relationships support the use of Chaoborus larvae as a Cd biomonitor.
\end{abstract}

Keywords-Metallothionein Cadmium Chaoborus Biomonitor Lake

\section{INTRODUCTION}

Larvae of the phantom midge Chaoborus have been proposed for use as biomonitors of the trace metal cadmium $(\mathrm{Cd})$. They are well suited to this task because they are common in lakes world wide [1,2] and tolerate a wide range of $\mathrm{pH}(4-$ 7.5) and Cd concentrations [3]. Most important, Cd concentrations in this putative biomonitor are consistently related to those in lakewater, even in highly metal-contaminated lakes [3]. It follows then that this insect is able to accumulate $\mathrm{Cd}$ without ill effect. To do so, this invertebrate likely possesses an effective $\mathrm{Cd}$ detoxification mechanism.

Metallothioneins are metal-binding proteins that are reported to play a key role in the binding and transport of $\mathrm{Cd}$ and other trace metals in animals [4]. These ubiquitous, lowmolecular weight, cysteine-rich proteins have been found in several genera of aquatic insects, including Chironomus (Diptera; [5]), Baetis (Ephemeroptera; [6]), and Eusthenia (Plecoptera; [7]). There are, however, no published reports that metallothionein-like proteins exist in Chaoborus larvae.

In this article, we set out first to determine if Chaoborus larvae posses a metal-binding protein having the characteristics of metallothionein (MT). To achieve this, we collected Chaoborus larvae in large numbers; a minimum of several hundred individuals was required to provide enough biomass for a single sample. An ability to synthesize MT would explain, in part, the capacity of this insect to exist in metal-contaminated lakes. Second, because sympatric Chaoborus species are reported to vary in their $\mathrm{Cd}$ concentrations [8], we collected samples of more than one species in lakes where population densities allowed; we speculated that a lack of MT could lead to the restriction of some Chaoborus species to relatively uncontaminated lakes. Third, we measured $\mathrm{Cd}, \mathrm{Cu}$, and $\mathrm{Zn}$ con-

* To whom correspondence may be addressed (landis@inrs-eau.uquebec.ca). centrations in larvae to determine if larvae with high MT concentrations had correspondingly high concentrations of these trace metals. A strong correlation between the concentrations of MT and $\mathrm{Cd}$ but not those of $\mathrm{Cu}$ or $\mathrm{Zn}$ would suggest that $\mathrm{Cd}$ is the metal responsible for MT induction in larvae.

\section{METHODS}

\section{Collection of field samples}

Water samples and larvae of three species of Chaoborus were collected in September 1999 from 10 lakes located on the Canadian Shield (Table 1) in the Quebec City area (QC) and in the mining areas of Sudbury (ON) and Rouyn-Noranda (QC). One of the lakes in the Rouyn-Noranda region, Lake Turcotte, has been directly impacted by the dumping of mining residues and subsequent liming.

Insect larvae were collected after sunset by hauling a 250 $\mu \mathrm{m}$ plankton net horizontally in the water column of each lake until a sufficient number of Chaoborus was obtained. Insects were maintained at field temperatures and transported to the laboratory in plastic bags filled with lakewater. In the laboratory, Chaoborus larvae were sorted according to species [1]. Where numbers permitted, three replicate samples of 300 to 1,000 similar-sized fourth instar larvae of each species were sealed in polyethylene bags, frozen, and stored in liquid nitrogen. At the end of the sampling trip, frozen samples were sealed in plastic bags filled with nitrogen and were stored at $-80^{\circ} \mathrm{C}$ for six months until homogenization.

Water samples were collected using in situ diffusion samplers (peepers) similar to those described by Carignan et al. [9]. These Plexiglas samplers comprise eight compartments of $4 \mathrm{ml}$ each that were filled with ultrapure water $(>18 \mathrm{M} \Omega \mathrm{cm})$ and separated from lakewater by a $0.2-\mu \mathrm{m}$ polysulfone membrane (Gelman HT-200; Pall Life Sciences, Ann Arbor, MI, USA). After preparation, each sampler was sealed in a clean plastic bag prior to placement in the field. Two diffusion sam- 
Table 1. Location of the study lakes (codes in parentheses) with their total dissolved concentrations of the trace metals $\mathrm{Cd}, \mathrm{Cu}$, and $\mathrm{Zn}$ as well as their $\mathrm{pH}$ and the concentration of dissolved organic carbon (DOC) and calcium (Ca)

\begin{tabular}{|c|c|c|c|c|c|c|c|}
\hline Region and lake & Location & $\mathrm{pH}$ & {$[\mathrm{Cd}](\mathrm{nM})$} & {$[\mathrm{Cu}](\mathrm{nM})$} & {$[\mathrm{Zn}](\mathrm{nM})$} & {$[\mathrm{Ca}](\mu \mathrm{M})$} & $\begin{array}{c}{[\mathrm{DOC}]} \\
(\mathrm{mg} \mathrm{C} / \mathrm{L})\end{array}$ \\
\hline \multicolumn{8}{|c|}{ Québec, Québec, Canada } \\
\hline Bertrand (BE) & $46^{\circ} 58^{\prime} \mathrm{N}, 72^{\circ} 01^{\prime} \mathrm{W}$ & 5.2 & 0.3 & 2.6 & 100 & 8 & 5.6 \\
\hline Laflamme (LA) & $47^{\circ} 19^{\prime} \mathrm{N}, 71^{\circ} 07^{\prime} \mathrm{W}$ & 6.7 & 0.1 & 2.6 & 22 & 17 & 5.5 \\
\hline St. Joseph (SJ) & $46^{\circ} 55^{\prime} \mathrm{N}, 71^{\circ} 40^{\prime} \mathrm{W}$ & 6.7 & 0.03 & 5.2 & 10 & 19 & 3.3 \\
\hline \multicolumn{8}{|c|}{ Rouyn-Noranda, Québec, Canada } \\
\hline Bousquet (BO) & $48^{\circ} 14^{\prime} \mathrm{N}, 78^{\circ} 34^{\prime} \mathrm{W}$ & 6.7 & 0.6 & 53 & 39 & 45 & 14.5 \\
\hline Caron (CA) & $47^{\circ} 56^{\prime} \mathrm{N}, 78^{\circ} 58^{\prime} \mathrm{W}$ & 7.2 & 0.7 & 72 & 46 & 114 & 10.9 \\
\hline Marlon (MA) & $48^{\circ} 16^{\prime} \mathrm{N}, 79^{\circ} 04^{\prime} \mathrm{W}$ & 7.4 & 0.9 & 147 & 35 & 59 & 10.2 \\
\hline Turcotte $^{\mathrm{a}}(\mathrm{TU})$ & $48^{\circ} 18^{\prime} \mathrm{N}, 79^{\circ} 04^{\prime} \mathrm{W}$ & 5.2 & 8.7 & 134 & 2,427 & 30 & 4.6 \\
\hline \multicolumn{8}{|c|}{ Sudbury, Ontario, Canada } \\
\hline Crooked (CK) & $46^{\circ} 25^{\prime} \mathrm{N}, 81^{\circ} 02^{\prime} \mathrm{W}$ & 6.2 & 1.5 & 317 & 81 & 23 & 5.7 \\
\hline Crowley (CW) & $46^{\circ} 23^{\prime} \mathrm{N}, 80^{\circ} 59^{\prime} \mathrm{W}$ & 6.7 & 0.7 & 127 & 48 & 22 & 2.8 \\
\hline Tilton (TI) & $46^{\circ} 22^{\prime} \mathrm{N}, 81^{\circ} 04^{\prime} \mathrm{W}$ & 6.4 & 0.9 & 106 & 63 & 29 & 2.7 \\
\hline
\end{tabular}

a Manipulated lake.

plers were suspended in the epilimnion of each lake. After a 3 -d equilibration period ( $3 \mathrm{~d}$ is considered to be sufficient for peeper equilibration; Tessier and De Vitre, unpublished results), the diffusion samplers were retrieved and water was collected immediately for the measurement of organic and inorganic carbon, trace metals, and major cations and anions.

Samples $(4 \mathrm{ml})$ for organic carbon determination were removed from one compartment of each peeper using a pipette fitted with a persulfate-washed plastic tip and were injected into 4-ml glass bottles that had been previously heated for 6 $\mathrm{h}$ at $500^{\circ} \mathrm{C}$ and rinsed several times with ultrapure water. Samples $(1 \mathrm{ml})$ for inorganic carbon determination were removed with a syringe from a second compartment and were injected through a septum into preevacuated and prewashed glass tubes. From the same compartment, a sample $(1.5 \mathrm{ml})$ for dissolved $\mathrm{SO}_{4}$ and $\mathrm{Cl}$ analyses was collected with a plastic-tipped pipette and was injected into prewashed microcentrifuge tubes (1.5 $\mathrm{ml}$, high-density polyethylene). Samples for trace metals (Cd, $\mathrm{Cu}$, and $\mathrm{Zn}$; five compartments) and major cations $(\mathrm{Ca}, \mathrm{Mg}$, $\mathrm{Na}$, and $\mathrm{K}$; one compartment) were removed from the remaining compartments in each dialysis sampler by piercing the membrane with a pipette fitted with an acid-cleaned tip. These samples were injected into preacidified (53 $\mu$ l of 1.35 $\mathrm{N}$ Anachemia $\mathrm{HNO}_{3}$ ) high-density polyethylene bottles (4-ml capacity). On installation and retrieval dates, $\mathrm{pH}$ was measured with a portable $\mathrm{pH}$ meter (Microprocessor model HI9024/ HI9025; Hanna Instruments, Woonsocket, RI, USA) in water samples collected at the depth of the dialysis samplers using a Van Dorn bottle.

\section{Analyses}

To minimize inadvertent trace metal contamination, labware, water-sampling materials, and vials were soaked in $15 \%$ nitric acid and rinsed in ultrapure water prior to use.

\section{Metallothionein}

Partially thawed Chaoborus larvae were gently homogenized, on ice, under a nitrogen atmosphere with a 50-ml manually operated glass tissue grinder. Homogenization was performed with four volumes of a phosphate buffer solution $(0.02$ $\mathrm{M})$ adjusted to $\mathrm{pH}$ 7.5. A subsample $(1 \mathrm{ml})$ was centrifuged at $30,000 \mathrm{~g}$ for $30 \mathrm{~min}$ at $4^{\circ} \mathrm{C}$, and the supernatant was divided into four subsamples that were analyzed the same day for MT.
Additional subsamples of the tissue homogenate were allocated for determination of the dry-weight:wet-weight ratio (1 $\mathrm{ml})$ and $\mathrm{Cd}, \mathrm{Cu}$, and $\mathrm{Zn}$ concentrations $(1 \mathrm{ml})$.

Metallothionein concentrations in Chaoborus larvae were measured with a mercury-saturation assay adapted slightly from Dutton et al. [10] and described in detail in Couillard et al. [11]. As a quality control, recovery of a standard (MT from rabbit liver; Sigma-Aldrich, St. Louis, MO, USA; stoichiometry of 7 mole metal/mole MT) was determined with every assay; the mean recovery for three determinations was $86 \pm$ $8 \%$ (standard deviation). Metallothionein concentrations (i.e., [MT]) are mean values of both field and analytical replicates ( \pm standard error) and are expressed as nanomoles of metalbinding sites per gram of dry tissue weight.

\section{Metal analyses}

Tissue homogenates were freeze dried (FTS Systems ${ }^{\mathrm{TM}}$, Mountain View, CA, USA), weighed, and digested at room temperature in 4-ml high-density polyethylene vials with concentrated nitric acid (Aristar grade, $100 \mu \mathrm{l} / \mathrm{mg}$ dry wt sample) for $7 \mathrm{~d}$. Hydrogen peroxide ( $40 \mu \mathrm{l} / \mathrm{mg}$ dry wt sample) was added $24 \mathrm{~h}$ prior to final dilution with ultrapure water (760 $\mu 1 / \mathrm{mg}$ dry wt sample). Samples of similar weight of a certified reference material (lobster hepatopancreas, TORT-1, National Research Council of Canada) were submitted to the same digestion procedures during each analytical run. Trace metal concentrations measured in this reference material were consistently within the certified range. Cadmium concentrations in animals were analyzed by flameless atomic-absorption spectrophotometry (AAS, Spectra AA-30; Varian, Palo Alto, CA, USA), whereas $\mathrm{Cu}$ and $\mathrm{Zn}$ concentrations were measured by inductively coupled plasma atomic-emission spectroscopy (Vista; Varian).

Total dissolved $\mathrm{Cd}, \mathrm{Cu}$, and $\mathrm{Zn}$ concentrations in the peeper samples were measured by flameless AAS (SIMAA 6000; Perkin-Elmer, Norwalk, CT, USA). Certified reference water samples (riverine water reference material, National Research Council of Canada) were also analyzed for $\mathrm{Cd}, \mathrm{Cu}$, and $\mathrm{Zn}$ during each analytical run, and measured trace metal concentrations were consistently within the certified range. Major cation concentrations were measured by flame AAS (Spectra AA-20; Varian). Concentrations of $\mathrm{SO}_{4}$ and $\mathrm{Cl}$ were measured by ion chromatography (DX300; Dionex AutoIon, Sunnyvale, 
Table 2. Metal concentrations $(\mathrm{Cd}, \mathrm{Cu}$, and $\mathrm{Zn}, \pm 95 \%$ confidence interval) and metallothionein-like protein concentrations $(\mathrm{MT} \pm$ standard error) in final instar Chaoborus larvae as well as the ratio of tissue [Cd] to [MT]; sample numbers are given in parentheses

\begin{tabular}{|c|c|c|c|c|c|c|}
\hline Region and lake & Species & $\underset{(\mathrm{nmol} / \mathrm{g})}{[\mathrm{Cd}]}$ & $\underset{(\mathrm{nmol} / \mathrm{g})}{[\mathrm{Cu}]}$ & $\begin{array}{c}{[\mathrm{Zn}]} \\
(\mu \mathrm{mol} / \mathrm{g})\end{array}$ & $\begin{array}{l}{[\mathrm{MT}]} \\
\text { (nmole binding } \\
\text { sites/g dry wt) }\end{array}$ & $\mathrm{Cd} / \mathrm{MT}$ \\
\hline \multicolumn{7}{|c|}{ Quebec, Québec, Canada } \\
\hline Bertrand & americanus & $6.0 \pm 0.59(n=3)$ & $64 \pm 9(n=3)$ & $2.0 \pm 0.63(n=3)$ & $133 \pm 15(n=3)$ & 0.04 \\
\hline Laflamme & flavicans & $4.3 \pm 0.81(n=2)$ & $97 \pm 8(n=2)$ & $1.2 \pm 0.32(n=2)$ & $100 \pm 9(n=3)$ & 0.04 \\
\hline St. Joseph & punctipennis & $7.1 \pm 1.4(n=3)$ & $72 \pm 2(n=3)$ & $1.4 \pm 0.29(n=3)$ & $120 \pm 11(n=3)$ & 0.06 \\
\hline \multicolumn{7}{|c|}{ Rouyn-Noranda, Québec, Canada } \\
\hline Bousquet & $\begin{array}{l}\text { flavicans } \\
\text { punctipennis }\end{array}$ & $36 \pm 1.6(n=3)$ & $\begin{array}{r}102 \pm 5(n=3) \\
97(n=1)\end{array}$ & $\begin{array}{l}1.4 \pm 0.10(n=3) \\
1.5(n=1)\end{array}$ & $187 \pm 1(n=2)$ & 0.19 \\
\hline Caron & flavicans & $44 \pm 1.3(n=3)$ & $107 \pm 2(n=3)$ & $1.3 \pm 0.001(n=3)$ & $163 \pm 4(n=3)$ & 0.27 \\
\hline Marlon & punctipennis & $54 \pm 3.5(n=3)$ & $107 \pm 31(n=3)$ & $1.2 \pm 0.07(n=3)$ & $183 \pm 2(n=3)$ & 0.29 \\
\hline Turcotte & americanus & $43 \pm 5(n=3)$ & $100 \pm 8(n=3)$ & $1.6 \pm 0.03(n=3)$ & $179 \pm 7(n=3)$ & 0.24 \\
\hline & punctipennis & $15 \pm 0.9(n=2)$ & $122 \pm 1(n=2)$ & $1.2 \pm 0.001(n=2)$ & $193 \pm 11(n=2)$ & 0.08 \\
\hline \multicolumn{7}{|c|}{ Sudbury, Ontario, Canada } \\
\hline Crooked & punctipennis & $72 \pm 2(n=3)$ & $145 \pm 12(n=3)$ & $1.2 \pm 0.06(n=3)$ & $199 \pm 5(n=3)$ & 0.36 \\
\hline Crowley & punctipennis & $130 \pm 5(n=3)$ & $164 \pm 13(n=3)$ & $1.0 \pm 0.05(n=3)$ & $196 \pm 14(n=3)$ & 0.66 \\
\hline \multirow[t]{2}{*}{ Tilton } & flavicans & $125(n=1)$ & $171(n=1)$ & $1.7(n=1)$ & $230(n=1)$ & 0.54 \\
\hline & punctipennis & $141(n=1)$ & $138(n=1)$ & $1.3(n=3)$ & $268(n=1)$ & 0.53 \\
\hline
\end{tabular}

CA, USA). Dissolved inorganic carbon concentrations were obtained by gas chromatography (GC 5890 Series 2: HewlettPackard, Palo Alto, CA, USA), and dissolved organic carbon concentrations were obtained with a total organic carbon analyzer (TOC-5000A; Shimadzu, Kyoto, Japan) using the combustion-infrared method. The Windermere humic aqueous model ([12]; Tipping, Ambleside, UK) was used to estimate free metal ion concentrations, with the assumptions discussed in Croteau et al. [3].

\section{RESULTS AND DISCUSSION}

\section{Metallothionein in Chaoborus}

The three species of Chaoborus present in our study lakes all possess a metal-binding protein that has features consistent with those of MT, i.e., a strong affinity to form complexes with $\mathrm{Hg}$ (stronger than those with $\mathrm{Cd}, \mathrm{Cu}$, or $\mathrm{Zn}$ ), thermostability, and acid resistance. The concentrations of MT-like protein ranged from 100 to $270 \mathrm{nmol}$ binding sites/g (Table 2), which is slightly lower than those found for the freshwater bivalve Pyganodon grandis (163-414 nmol binding sites/g dry wt; [11]) but higher than those found in the mayfly Hexagenia limbata (18-106 nmol binding sites/g dry wt; Y. Couillard, unpublished data). The presence of a metal-binding protein in Chaoborus larvae could explain in part their accumulation of and tolerance to trace metals. Increased metal resistance has been associated with MT induction in other aquatic (mayflies [6], chironomids [13]) and terrestrial (collembolans [14]) insects.

Because all of the Chaoborus species that we studied appear to have a MT-like protein (Table 2), the presence or absence of such a protein cannot explain differences in $\mathrm{Cd} \mathrm{ac}$ cumulation among them [8]. In contrast, Aoki et al. [6] reported marked species-to-species differences for the mayfly Baetis; a species present in metal-contaminated streams possessed a MT-like protein, whereas two others that did not were restricted to uncontaminated rivers.

We compared the concentrations of Cd and MT-like protein in Chaoborus species from the same lake. In the two lakes in which they coexisted (Lakes Tilton, ON, and Bousquet, QC, Canada; Table 2), larvae of Chaoborus punctipennis had high- er concentrations of a MT-like protein and the same or higher concentrations of $\mathrm{Cd}$ than did larvae of Chaoborus flavicans. In contrast, the concentrations of MT-like protein in C. punctipennis were not significantly different from those in Chaoborus americanus (Lake Turcotte, $t$ test, $p=0.34$ ), in spite of the fact that $\mathrm{Cd}$ concentrations in the former species were three times lower than those of the latter species ( $t$ test, $p=$ 0.004). This apparent inconsistency could result from the small number of samples that we were able to collect for analysis. The large number of larvae $(300-1,000)$ that had to be sorted to prepare a single sample limited the number of samples that we could prepare. More data are clearly required to explain species-specific differences in the relationship between $\mathrm{Cd}$ contamination levels in Chaoborus and their MT-like protein levels.

\section{Concentrations of larval Cd and MT-like protein}

The concentrations of MT-like protein in Chaoborus were directly related to larval Cd concentrations (Fig. 1a, $p<0.01$ ). Several previous studies have reported a linear relationship between the concentrations of MT and those of $\mathrm{Cd}$ in aquatic animals $[11,15,16]$. However, a curvilinear relationship also fits our data well $(p<0.001)$, i.e., there appears to be a plateau in concentrations of the MT-like protein at approximately 200
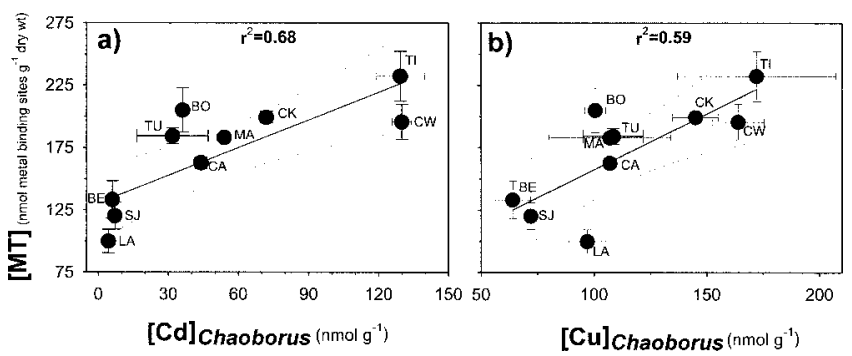

Fig. 1. Metallothionein-like protein concentrations (MT \pm standard error) in larvae of the genus Chaoborus as a function of their (a) $\mathrm{Cd}$ concentrations ( \pm standard deviation) and (b) $\mathrm{Cu}$ concentrations $( \pm$ standard deviation). Data for the manipulated Lake Turcotte, Quebec, Canada (TU), were excluded from statistical analyses. Each point corresponds to a particular lake (see Table 1 for lake codes). 
nmol binding sites/g dry weight (Fig. 1a). We would require data from larger number of lakes to choose credibly between these alternatives.

In contrast, there was no relationship between the concentrations of larval $\mathrm{Zn}$ and the MT-like protein $(p=0.53)$, a result that is consistent with the reported ineffectiveness of ambient $\mathrm{Zn}$ in inducing MT-like proteins both in the laboratory [17] and in the field [11]. However, there was a significant relationship between larval $\mathrm{Cu}$ and MT-like protein concentrations (Fig. 1b, $p=0.01$ ). Since we do not see a correlation between MT and external ambient $\mathrm{Cu}$, we do not think that $\mathrm{Cu}$ is acting to induce MT biosynthesis. Rather, we suggest that MT concentrations increase as a result of $\mathrm{Cd}$ exposure and that this induced MT then acts as a competitive ligand within the cytosol and sequesters part of the available $\mathrm{Cu}$ [18]. Since copper is an essential micronutrient, the organism will tend to compensate for this lowering of the internal free $\mathrm{Cu}^{2+}$ concentration by increasing total copper levels in the cytosol. The overall result is an increase in cytosolic $\mathrm{MT}, \mathrm{Cd}$, and $\mathrm{Cu}$ and the observation of a correlation between $\mathrm{Cd}$ and $\mathrm{Cu}$ concentrations in larvae $\left(r^{2}=0.95, p<0.01\right)$.

If the rate of metal influx exceeds the net rate of metalbinding protein biosynthesis, incoming excess metal could bind nonspecifically to other intracellular ligands. This phenomenon, often termed spillover [19], would correspond to the onset of potential adverse effects of the metal on the animal. We evaluated spillover in a simplistic way by calculating the ratio of tissue [Cd] to [MT-like protein] (Table 2). The MTlike protein concentrations in Chaoborus larvae were more than sufficient to bind all of the $\mathrm{Cd}$ in the insect, suggesting that no Cd spillover occurred. Although this result is consistent with the presence of this animal in metal-contaminated lakes, our simplistic scenario ignores the presence of $\mathrm{Cu}$ that is also likely to be bound to the MT-like protein and the fact that an unknown proportion of the $\mathrm{Cd}$ is not in the cytosol and thus not bound to MT.

\section{Relationships between $M T, C d$ in the insect, and $C d$ in water}

Despite an extremely wide range of $\mathrm{Cu}$ and $\mathrm{Zn}$ concentrations in our study lakes (Table 1), Chaoborus $\mathrm{Cu}$ and $\mathrm{Zn}$ varied little among lakes ( $p>0.05$; Table 2), suggesting that Chaoborus larvae are able to regulate the concentrations of these essential metals $[3,20]$. Ignoring highly manipulated Lake Turcotte, larval $\mathrm{Cd}$ concentrations were directly related to those in water (Fig. $2 \mathrm{a}, p<0.01$ ). Lake Turcotte remains an outlier even if we take into account the competitive influence of hydrogen ions and other cations on $\mathrm{Cd}$ bioaccumulation using the approach described by Hare and Tessier [3,21]. Thus, we chose to exclude Lake Turcotte from our statistical analyses but to retain it for comparative purposes in the figures. Metallothionein-like protein concentrations in Chaoborus were directly related to concentrations of the free $\mathrm{Cd}^{2+}$ ion (Fig. 2b, $p<0.001)$. A direct relationship has also been reported for a bivalve mollusk [11], but there have been few other comparable studies in nature. If all of the $\mathrm{Cd}$ in Chaoborus were in the cytosol, then we might expect to observe a stronger relationship between MT and Cd in Chaoborus $\left(r^{2}=0.68\right)$ than between MT in Chaoborus and Cd in water $\left(r^{2}=0.89\right)$. Based on the $r^{2}$ values for these relationships, the reverse was the case, suggesting that part of the $\mathrm{Cd}$ in Chaoborus is bound to cell fractions other than MT that are less bioreactive (granules, membranes, etc.). The corollary to this observation is that the
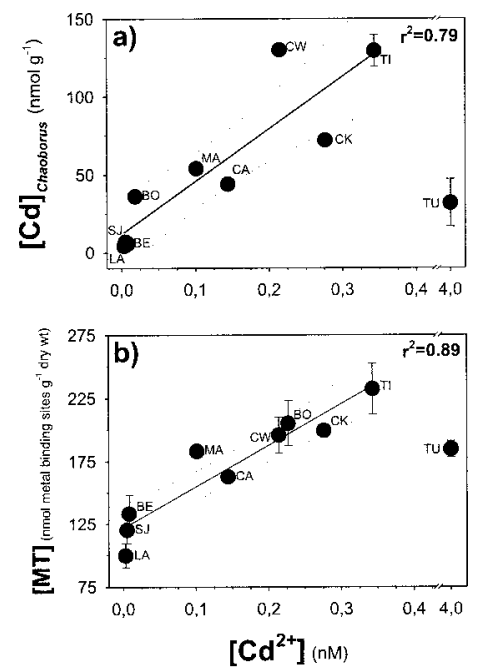

Fig. 2. Relationships between (a) Cd concentrations in larvae of the genus Chaoborus ( \pm standard deviation) and free $\mathrm{Cd}$ ion concentrations and (b) metallothionein-like protein concentrations (MT \pm standard error) in larvae of the genus Chaoborus and free Cd ion concentrations. Data for the manipulated Lake Turcotte, Quebec, Canada (TU), were excluded from statistical analyses. Each point corresponds to a particular lake (see Table 1 for lake codes).

concentrations of MT-like protein in larvae of the insect Chaoborus could thus be used to monitor the concentrations of bioreactive $\mathrm{Cd}$, i.e., the concentration of internal $\mathrm{Cd}$ that was able to initiate a biochemical response.

Acknowledgement-Funding was provided by the Metals in the Environment Research Network (contribution 20), Ontario Power Generation, the Mining Association of Canada, Human Resources Development Canada, the Natural Sciences and Engineering Research Council of Canada, and the Québec Fonds pour la Formation de Chercheurs et l'Aide à la Recherche. The technical assistance of M. G. Bordeleau, M.-R. Doyon, P. Fournier, A. Giguère, P. Marcoux, S. St. Pierre, and R. Rodrigue is acknowledged.

\section{REFERENCES}

1. Saether OA. 1972. Chaoboridae. In Elster HJ, Ohle W, eds, Das Zooplankton der Binnengewässer. E. Schweizerbart'sche, Stuttgart, Germany, pp 257-304.

2. Hare L, Carter JCH. 1986. The benthos of a natural West African lake, with emphasis on the diel migrations and lunar and seasonal periodicities of the Chaoborus populations (Diptera, Chaoboridae). Freshw Biol 16:759-780.

3. Croteau M-N, Hare L, Tessier A. 1998. Refining and testing a trace metal biomonitor (Chaoborus) in highly acidic lakes. Environ Sci Technol 32:1348-1353.

4. Roesijadi G. 1992. Metallothioneins in metal regulation and toxicity in aquatic animals. Aquat Toxicol 22:81-114.

5. Yamamura M, Suzuki KT, Hatakeyama S, Kubota K. 1983. Tolerance to cadmium and cadmium-binding proteins induced in the midge larva, Chironomus yoshimatsui (Diptera, Chironomidae). Comp Biochem Physiol C 75:21-24.

6. Aoki Y, Hatakeyama S, Kobayashi N, Sumi Y, Suzuki T, Suzuki KT. 1989. Comparison of cadmium-binding protein induction among mayfly larvae of heavy metal resistant (Baetis thermicus) and susceptible species (B. yoshinensis and B. sahoensis). Comp Biochem Physiol C 93:345-347.

7. Everard L, Swain R. 1983. Isolation, characterization and induction of metallothionein in the stonefly Eusthenia spectabilis following exposure to cadmium. Comp Biochem Physiol C 75:275280.

8. Croteau M-N, Hare L, Tessier A. 2001. Differences in Cd accumulation among species of the lake-dwelling biomonitor Chaoborus. Can J Fish Aquat Sci 58:1737-1746.

9. Carignan R, Rapin R, Tessier A. 1985. Sediment pore-water sam- 
pling for metal analysis: A comparison of techniques. Geochim Cosmochim Acta 49:2493-2497.

10. Dutton MD, Stephenson M, Klaverkamp JF. 1993. A mercury saturation assay for measuring metallothionein in fish. Environ Toxicol Chem 12:1193-1202.

11. Couillard Y, Campbell PGC, Tessier A. 1993. Response of metallothionein concentrations in a freshwater bivalve (Anodonta grandis) along an environmental cadmium gradient. Limnol Oceanogr 38:299-313.

12. Tipping E. 1994. WHAM-A chemical equilibrium model and computer code for waters, sediments, and soils incorporating a discrete site/electrostatic model of ion-binding by humic substances. Comput Geosci 20:973-1023.

13. Postma JF, Kyed M, Admiraal W. 1995. Site specific differentiation in metal tolerance in the midge Chironomus riparius (Diptera, Chironomidae). Hydrobiologia 315:159-165.

14. Hensbergen PJ. 1999. Metallothionein in Orchesella cincta. $\mathrm{PhD}$ thesis. Vrije Universiteit, Amsterdam, The Netherlands.

15. Bebianno MJ, Langston WJ. 1991. Metallothionein induction in Mytilis edulis exposed to cadmium. Mar Biol 108:91-96.
16. Wang D, Couillard Y, Campbell PGC, Jolicoeur P. 1999. Changes in subcellular metal partitioning in the gills of freshwater bivalves (Pyganodon grandis) living along an environmental cadmium gradient. Can J Fish Aquat Sci 56:774-784.

17. Roesijadi G, Unger ME, Morris JE. 1988. Immunochemical quantification of metallothioneins of a marine mollusc. Can J Fish Aquat Sci 45:1257-1263.

18. Gully JR, Mason AZ. 1993. Cytosolic redistribution and enhanced accumulation of $\mathrm{Cu}$ in gill tissue of Littorina littorea as a result of Cd exposure. Mar Environ Res 35:53-57.

19. Mason AZ, Jenkins KD. 1995. Metal detoxification in aquatic organisms. In Tessier A, Turner DR, eds, Metal Speciation and Bioavailability in Aquatic Systems. Wiley, New York, NY, USA, pp 479-608.

20. Hare L, Tessier A. 1998. The aquatic insect Chaoborus as a biomonitor of trace metals in lakes. Limnol Oceanogr 43:18501859.

21. Hare L, Tessier A. 1996. Predicting animal cadmium concentrations in lakes. Nature 380:430-432. 